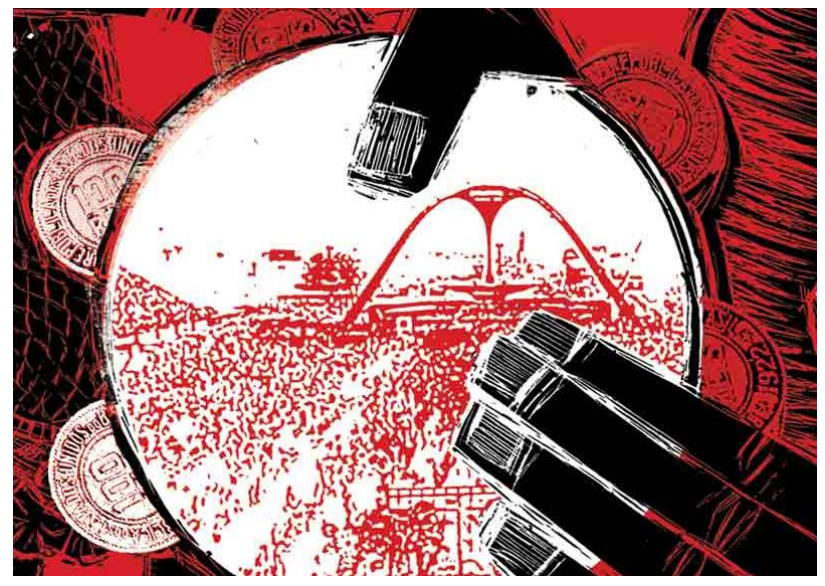

\title{
O filho da dor: espacialidades em Desde que o samba é samba, de Paulo Lins.
}

\author{
The son of the pain: spatialities in Desde que o samba é samba, by Paulo Lins.
}

\author{
Gabriel Capelossi Ferrone ${ }^{1}$
}

\section{Resumo:}

Este trabalho faz uma reflexão em torno de Desde que o samba é samba (2012), segundo romance de Paulo Lins, que recria e ficcionaliza o nascimento e desenvolvimento do Samba no bairro carioca Estácio na década de 1920. Serão apontadas as estratégias narrativas para a construção de múltiplas espacialidades no romance e como a história do Samba e da Umbanda atuam na mobilidade, ou não, das personagens. Além disso, será observada a presença de graus de violência a partir da relação geográfica que os personagens dispõem entre si. Por fim, terão ênfase os múltiplos espaços, simbólicos e físicos, que, ora apresentam tensões e rivalidades desenvolvidas a partir de um relacionamento conturbado entre as pessoas que os dividem, ora aproximam-nas, impulsionadas pelos elementos culturais locais.

Palavras-chave: Espacialidade. Deslocamento. Samba. Umbanda. Violência.

\section{Abstract}

This work reflects on Since samba é samba (2012), the second novel by Paulo Lins, which recreates and fictionalizes the birth and development of Samba in the Rio neighborhood of Estácio in the 1920s. Narrative strategies will be pointed out for the construction of multiple spatialities in the novel and how the history of Samba and Umbanda act on the mobility, or not, of the characters. In addition, the presence of degrees of violence will be observed based on the geographical relationship that the characters have among themselves. Finally, emphasis will be placed on the multiple spaces, both symbolic and physical, which, in turn, present tensions and rivalries developed from a troubled relationship between the people who divide them and sometimes bring them closer, driven by the local cultural elements.

Keywords: Spatiality. Displacement. Samba. Umbanda. Violence.

\footnotetext{
${ }^{1}$ Professor e bacharel em Letras graduado pela Universidade Estadual Paulista "Júlio de Mesquita Filho", UNESP, campus Araraquara. Discente do Programa de Pós-Graduação em Estudos Literários (mestrado) pela mesma instituição. Residente em: R. Américo Salles, 619, Centro, Jardinópolis/SP. gabrielcapelossi@hotmail.com
} 


\section{Introdução}

Este artigo apresenta as reflexões que foram desdobradas a partir de discussões e apontamentos realizados ao longo da disciplina "Literatura e classes populares no Brasil", ministrada pelo prof. Dr. Julio Bastoni, em 2017, no Programa de Pós-Graduação em Estudos de Literatura da Universidade Federal de São Carlos.

Paulo Lins nasceu e morou em Cidade de Deus ${ }^{2}$, formou-se em uma universidade pública e escreveu seu primeiro romance ${ }^{3}$ a partir de uma pesquisa antropológica da Universidade Federal do Rio de Janeiro (UFRJ) sobre sua própria favela, que pode ser lido como uma ficcionalização de fatos reais (SCHOLLHAMMER, 2013), haja vista sua história pessoal. Em 2012, Lins publicou seu segundo romance, Desde que o samba é samba, em que recria e ficcionaliza o nascimento e desenvolvimento do gênero Samba no bairro carioca Estácio, em meados da década de 1920. É para essa produção, com fortuna crítica ainda pequena, que as discussões deste trabalho serão norteadas. Será enfatizado, principalmente, como os diferentes espaços construídos na narrativa ora apresentam tensões e rivalidades desenvolvidas a partir de um relacionamento conturbado entre as pessoas que os dividem, ora aproximam-nas, impulsionadas pelos elementos culturais locais - Samba e Umbanda.

Georg Wink, em seu artigo "Topografias literárias e mapas mentais: a sugestão de espaços geográficos e sociais na literatura", primeiro dos textos que compõem o livro Espaços possíveis na literatura brasileira contemporânea (DELCASTAGNÈ, 2015), propõe que o espaço construído em uma narrativa nem sempre é planejado de maneira "ingênua ou coincidencial, mas, sim, que pertence às estratégias narrativas e, portanto, cumpre uma função de relevância para a análise literária” (WINK, 2015, p. 21). À vista disso, devemos indagar, então, o papel das diferentes espacialidades presentes na ficcionalização construída por Lins em seu segundo romance.

Com um olhar panorâmico, é possível perceber que o autor apresenta um triângulo amoroso entre uma prostituta, Valdirene, um malandro, cafetão e capoeirista, Brancura, e um português, funcionário do Banco do Brasil, Sodré, ao mesmo tempo que evidencia ao leitor uma relação violenta entre o bairro Estácio, marginalizado, e o centro carioca.

\footnotetext{
${ }^{2}$ Bairro da cidade do Rio de Janeiro onde, na década de 1960, recebeu vários conjuntos habitacionais que foram construídos para remoção da população das favelas de outras áreas da cidade.

${ }^{3}$ LINS, P. Cidade de Deus. São Paulo: Companhia das Letras, 1997.
} 
Historicamente, a trama é inserida no momento pós-abolição, época marcada por uma reorganização espacial imposta aos moradores do Rio de Janeiro. Essa reorganização forçou especialmente negros e mestiços a se estabelecerem em morros e bairros à margem do centro da cidade. Por isso, é possível ler Desde que o samba é samba (2012) como uma continuação de Cidade de Deus (1997) em uma espécie de antecipação da história. "É como se alguém perguntasse pelos trisavôs de Zé Pequeno, para compreender como a explosão da violência nas comunidades cariocas da década de 1980 foi preparada" (DRUCKER, 2012, p.242). Um estudo histórico e sociológico sobre as tensões constitutivas das espacialidades na História brasileira permite-nos apontar que o Rio de Janeiro - que abarca o Morro do Estácio, cenário de Lins - passou por

Intensas modificações urbanísticas, desencadeadas pela reforma de Pereira Passos, com a abertura da Avenida Central e a expulsão de muitas famílias negras e pobres (entre elas muitas famílias baianas que haviam se mudado para o Rio de Janeiro depois da Abolição da Escravatura, trazendo em sua bagagem o Candomblé e vários ritmos do samba, que aqui foram transformados no samba carioca) do Centro da cidade para, num primeiro momento, a Cidade Nova e, depois, para os subúrbios e favelas. (VIANNA, 2012, p. 112-113)

Em seu primeiro romance, Lins apresenta a violência policial e a falta de políticas públicas, por exemplo, como elementos sine qua non para os desdobramentos narrativos embebidos em uma violência brutal que choca o leitor e, mais tarde, o telespectador ${ }^{4}$. Já em Desde que o samba é samba (2012), a dicotomia entre favela/centro da cidade e o apagamento autoral dos sambistas para que suas músicas sejam reconhecidas em espaços além-morro retratam a violência sofrida especialmente por aqueles que sobrevivem nos espaços de exclusão (PELLEGRINI, 2004). Há, entretanto, uma diferença primordial entre as tramas de ambos os romances e suas relações com as respectivas violências: enquanto em Cidade de Deus (1997) ela norteia os acontecimentos narrados, em Desde que o samba é samba (2012) há uma subordinação da violência por parte dos elementos culturais do morro: a música e a religião.

É importante apontar que a concepção de violência pode ser tomada essencialmente de duas maneiras ao longo da segunda narrativa de Lins: pela ótica do dominado e pela ótica do dominador. Para entender melhor essa dualidade, Darcy Ribeiro, em O povo brasileiro: a formação e o sentido do Brasil (2015), sugere uma estratificação

\footnotetext{
${ }^{4}$ A esse respeito, consultar Melo (2004) sobre as narrativas fílmica e romanesca, Matte (2015) sobre perversidade, fábula e utopia e Schollhammer (2013) sobre violência e realismo.
} 
da nação a partir da formação marxista clássica modificada de acordo com os moldes de formação histórico nacional. Para ele, a sociedade brasileira é formada pelos dominantes, pelos intermediários, pelos subalternos e oprimidos. A diferença entre os dois últimos se dá na relação que têm com o trabalho: enquanto o subalterno é o trabalhador empregado e formalmente assalariado, o oprimido se encontra fora deste sistema formal de trabalho, como a prostituição e trabalhos eventuais, por exemplo.

Logo, a relação de violência no romance depende da ótica social porque, do ponto de vista dominante, o oprimido representa uma irrupção na ordem social - com rodas de samba, terreiros e prostíbulos - e do ponto de vista daquele que ocupa uma posição marginal, a violência se dá, por exemplo, com a perseguição estatal - por meio de decretos e leis - àquele que melhor representa sua classe: o malandro - que nasce a partir de uma penúria material e de uma dificuldade de delimitação entre a legalidade e a ilegalidade.

É importante apontar que este tipo social é tomado, inclusive, como uma representação metonímica - ainda que ingênua - do caráter nacional, uma vez que aponta, segundo DaMatta (1990), o dilema da sociedade brasileira entre seguir o conjunto rígido de legislações universais e a flexibilização branda das relações interpessoais. Sobre isso, Schollhammer (2013, p.51) aponta:

O malandro brasileiro é um andarilho (mal andar: malandro), um homem sem compromisso, um tipo picaresco que se comporta como um peixe nas águas do samba, do carnaval, do jogo e das favelas, sempre no limite da lei, mas nunca em total oposição a ela. [...] Segundo esse mito folclórico tipicamente brasileiro, o malandro sobrevive em função do seu talento individual e não da organização criminosa, é avesso ao batente, bom de briga e rápido na faca, mas raramente usa arma de fogo, evita o confronto direto e prefere o "jeitinho", a fuga ou a boa conversa, mantendo o equilíbrio entre a ordem e a desordem. $\mathrm{O}$ malandro, que se reconhece por atuar sempre com certa graça, charme, apesar da sua falta de moral e sociabilidade, permanece como figura característica da marginalidade do morro, do samba e do jeitinho "fora da lei" tipicamente brasileiro.

Em Desde que o samba é samba (2012), a personagem principal da trama não é o "bandido que é jovem, malnutrido, com dentes ruins, analfabeto e sem opções, como milhões de brasileiros nascidos nas décadas de 1970 e 1980" (SCHOLLHAMMER, 2013, p. 58), mas o malandro, que atua "sempre com certa graça, charme, apesar da sua falta de moral e sociabilidade" (SCHOLLHAMMER, 2013, p. 51), esquivando-se das obrigações sociais, embora no fundo fosse totalmente dependente dela. $\mathrm{O}$ malandro apresentado por Lins é o responsável por representar uma violência que independe de revólveres e balas, que usa a navalha e os punhos para manter uma organização social local apesar de 
subordinar-se às estruturas estatais de poder - como a polícia - e que participa da gestão de elementos culturais - samba e Umbanda - posteriormente associados ao espaço em que vivem, o morro.

\section{O espaço de pertencimento}

Desde que o samba é samba (2012) é situado em um momento histórico definido e é composto por elementos que fazem parte da historiografia popular nacional, como Brancura, apelido do sambista Silvio Fernandes, o ritmista Osvaldo Caetano Vasques, vulgo Baiaco, Ismael Silva, tratado no livro apenas como Silva, Mario de Andrade e Manuel Bandeira. Em contrapartida, Lins também constrói personagens fictícios que se entrelaçam com a realidade: a prostituta Valdirene e o português Sodré. Essa composição produzida pelo autor faz com que a trama possa ser lida como um romance histórico, ainda que ele, autor, não tenha propriamente assumido essa característica ${ }^{5}$. Esse cunho historiográfico pode ser atribuído ao livro também pela figura do malandro que, até hoje, como aponta Dealtry (2009, p. 48):

É um termo carregado de historicidade, remetendo-nos inexoravelmente aos sambistas ou aos valentões da Lapa dos anos 30; 'malandragem' torna-se uma prática - um conjunto de estratégias - que, até certo ponto, independe da classe social ou da geografia da cidade.

Giovanna Dealtry apresenta a imagem do "malandro ideal" ligada à figura do sambista prototípico: navalha, terno branco e chapéu. Segundo a autora, esse tipo social é composto por um conjunto de características que não foi apagado do imaginário nacional somente pelo "desaparecimento das conjunções históricas e culturais que permitiam a existência desse malandro" (DEALTRY, 2009, p. 48), mas, sim, transformado em mito. "E como mito, ele pode ser acessado periodicamente, de acordo com os interesses do momento" (DEALTRY, 2009, p. 48).

Ser malandro, especialmente na primeira metade do século XX, tempo histórico da narrativa de Lins (2012), exigia, de certa forma, um conjunto de conhecimentos de mundo e de relações de poder que serviam para alavancar o status quo daquele que era cafetão, sambista, boêmio e que geralmente fugia da polícia por ser considerado vagabundo. Brancura, um dos personagens principais do romance, passa por uma espécie

\footnotetext{
5 Sobre isso, consultar https://oglobo.globo.com/cultura/desde-que-samba-samba-novo-livro-de-paulo-
} lins-4512115 
de processo educacional ao longo da narrativa até tornar-se verdadeiramente um malandro. Aos quinze anos, é levado à força para a zona no dia de seu aniversário pelo seu pai, movido por uma crença homofóbica:

Pai que não o criou, que, quando soube que a mulher engravidara, tratou de lhe dar chá de broto de pé de café na intenção de provocar um aborto. [...] Seu pai fez o que a mãe pediu no seu segundo mês de gravidez: sumiu de sua vida. [...] Rafael só apareceu na casa do filho quando este fez quinze anos, na hora de cantar Parabéns, para levar o menino à força para a zona. [...] Acreditava que se não fizesse isso antes de cantar os Parabéns dos quinze anos do filho, o menino se tornaria veado. E para ele, veado bom era veado morto. (LINS, 2012, p. 50-51)

A decisão de Rafael deixou Brancura cheio de vergonha e com raiva de seu pai: queria evitá-lo, não queria encontrá-lo. Porém, pouco tempo depois, teve sua segunda relação sexual e a comparou com a prostituta que seu pai lhe havia apresentado. Decidiu procurá-la novamente, o que fez com que estabelecesse os primeiros vínculos com um lugar de aparente desordem e ilegalidade.

A segunda relação sexual de Brancura se deu atrás da igrejinha, com Márcia. Só aí se deu conta de como Fátima sabia das coisas. [...] Relutou, até que um dia bateu à porta de Fátima, depois de se certificar de que o pai não estava na zona. (LINS, 2012, p. 52)

Nem mesmo o mais sincero sentimento de aversão foi capaz de manter Brancura distante de seu pai quando o avistou sendo agredido por três homens. A cena narrada por Lins evidencia que Brancura, ainda que com apenas 15 anos, já estava inserido em um ambiente composto por códigos de honra e violência. Mais uma vez, o garoto deparavase com uma situação que o modelava para que fosse inserido na comunidade em que vivia como um malandro:

O pai estava metido de novo em confusão, coisa que acontecia quase diariamente. [...] Foi andando para outro lado, ganhando distância. Estava determinado a sumir dali, mas não, seu genitor estava sofrendo uma covardia. Podia ser o pior pai do mundo, mas o sangue era o mesmo, não ia deixa-lo no perrengue. Saiu em disparada, pulou com os dois pés no peito do homem que batia em seu pai. [...] Brancura encarou os três agressores com valentia, usava golpes de capoeira numa briga de verdade pela primeira vez. (LINS, 2012, p. 53)

Mais tarde, Rafael, que era cafetão, propôs ao filho que aprendesse todos os truques de sua profissão.

Quando o pai achou que o filho estava apto, falou para Fátima que ela poderia entregar a filha [Valdirene] ao rapaz, que este já estava no ponto para defender qualquer puta que fosse. Sabia de cor e salteado os 
segredos da zona. Parecia que tinha nascido para aquilo. (LINS, 2012, p. 60)

Depois desses fatos, Brancura organizou sua vida para que mantivesse a ordem e a harmonia na zona - ainda que tivesse que utilizar a violência para isso. Com o tempo, herdou os negócios do pai após sua morte e já não mais voltava para casa para passar as noites com suas mulheres:

Tornara-se tudo aquilo que sua família não queria. [...] A mãe que se arrependeu de deixar o filho aproximar-se do pai, só o fez pela avó do menino. É verdade, porém, que acreditou no pai de seu filho: com a presença da avó em casa, achou que ele daria novo rumo à vida. Que nada, o desgraçado não apenas continuou de nhenhenhém da zona como ainda levou Brancura, que se tornou mais vagabundo que o pai. Ainda por cima era sambista, beberrão e viciado em palmeirense. Mãe que ficou tão desgostosa com a vida do filho que foi morrendo aos poucos, de tão mãe que era, assim como as suas plantas, que deixara de regar. (LINS, 2012, p.61)

Com Brancura mais velho, rodeado por sambistas, cafetões e prostitutas, cliente assíduo do Bar do Apolo e andarilho conhecido por toda e qualquer viela do Morro do Estácio, Paulo Lins estrutura uma descrição de um malandro prototípico, de alguém que foi moldado desde sua infância para se tornar a figura maior do espaço em que vivia:

Brancura, desde rapazola, usava calça larga feito o pessoal da velha guarda, como os malandros da época. Começou a usar terno depois que se juntou a Silva, Bastos, Bide, Baiaco, e os demais compositores da região. Já eram pretos, pobres, morava em área vigiada pela polícia, se andassem mal arrumados só iriam piorar sua condição na sociedade. $\mathrm{E}$ mais: eram compositores, seriam famosos um dia como Alfredo, Barbosa e João, que usavam terno de manhã, de tarde, de noite, com os sapatos tão bem engraxados que reluziam à luz do sol ou da lua. E lá ia Brancura dentro de seu terno, em cima de seus sapatos pretos a qualquer hora que fosse, fazendo inveja àqueles malandros sem estirpe, sem o dom da arte, sem indumentária de classe. Atraía olhares desejosos das mulheres dentro e fora da zona. (LINS, 2012, p. 143)

Com relação às teorias da espacialidade, Michel de Certeau (2000) diferencia dois termos que podem ser aplicados às análises e críticas literárias: espaço e lugar. Para o francês, lugar é uma disposição dos seres e objetos em um determinado cenário sem a prática do movimento. Espaço, entretanto, é a dinamicidade construída por esses elementos, isto é, quando os indivíduos desenvolvem um caráter de mobilidade.

Brancura é, portanto, um alvo de constantes modificações interiores e exteriores ao longo do romance. É interessante perceber como a modelagem de sua personalidade e o seu relacionamento com os moradores do morro onde mora são desenvolvidos de 
maneira exponencial à medida em que se assume como um elemento pertencente ao lugar onde nasceu. Sua inserção e consecutiva facilidade de manipulação das relações de poder de seu contexto social transformam, dessa maneira, o lugar Estácio em um espaço social, composto por dinamicidades físicas e simbólicas.

É necessário apontar, entretanto, que o processo de transformação da figura malandra em mito nacional ocorreu não porque houve uma necessidade de valorização repentina deste ícone, mas, sim, porque se desenrolou um trabalho midiático abusivo de gravadoras e cantores já consagrados para fazer com que o samba descesse o morro e fosse aceito pelos componentes da classe dominante. Era comum que nomes já reconhecidos pela sociedade comprassem letras e melodias de sambistas marginalizados e não atribuíssem a eles as respectivas autorias musicais.

Esse procedimento foi ficcionalizado por Lins (2012), quando Silva, internado para receber tratamento contra sífilis, recebe a notícia de Bide sobre a proposta de Francisco Alves, cantor que recebeu grande notoriedade no início do século XX, para comprar o samba Me faz carinhos:

- Que que foi, rapaz?

- Tenho uma notícia pra você.

- Se for boa vai falando, se for ruim, pode ir embora, que eu tô doente...

- Tu não sabe o que Oxalá reservou pra você!

- Fala logo!

- Silva! Alves escutou Me faz carinhos na voz do Cebola e quer comprar teu samba.

$[\ldots]$ - Mas tem uma coisa...

- Que coisa?

- O samba sai só com o nome dele. Ele comprou, ele é o dono! Não tem macacada de parceria, não. (LINS, 2012, p. 151)

Norbert Elias e John L. Scotson em Os estabelecidos e os outsiders (2000) consolidaram um estudo que buscou esclarecer a relação entre grupos de pessoas que manejam e utilizam formas de poder para segregar, estigmatizar e, quiçá, condenar membros de grupos distintos:

Como se processa isso? De que modo os membros de um grupo mantêm entre si a crença em que são não apenas mais poderosos, mas também seres humanos melhores do que os outros? Que meios utilizam eles para impor a sua crença em sua superioridade humana aos que são menos poderosos? (ELIAS; SCOTSON, 2000, p. 20)

Ainda segundo os autores, a divisão social entre estabelecidos e outsiders foi construída a partir da temporalidade em que os grupos estavam inseridos em determinada área. Aqueles pertencentes às "famílias antigas" em uma mesma região sentiam-se 
superiores aos de comunidade mais recentemente formada. Em Desde que o samba é samba (2012), essa dicotomia social é bastante evidente: de um lado, o centro da cidade (homogeneamente branco) composto por uma elite econômica e política, propulsora de uma urbanização que acentuou essa diferenciação aqui descrita, os estabelecidos. Do outro, operários, malandros, prostitutas e mães de santo (majoritariamente negros) que foram forçadamente deslocados para os morros urbanos e margens sociais, os outsiders. Luis Edmundo, jornalista, historiador e cronista, afirmou: "No Rio de Janeiro, os que descem na escala da vida vão morar para o alto, instalando-se na livre assomada das montanhas, pelos chãos elevados e distantes, de difícil acesso.”. (1958, p. 199)

Elias e Scotson (2000) apontam, também, que os próprios "recém-chegados", passado algum tempo em sua nova localidade, começavam a aceitar a ideia de pertencimento a um grupo menos virtuoso e valorado. Entretanto, é certo afirmar que uma análise cuidadosa de determinada espacialidade permite que observemos que os sujeitos gravam suas experiências nela, ainda que subjugadas. Maurice Halbwachs em sua Memória Coletiva (2003), aponta

O grupo se fecha no contexto que construiu. A imagem do meio exterior e das relações estáveis que mantém com este passa ao primeiro plano da ideia que tem de si mesmo. Essa imagem penetra em todos os elementos de sua consciência, deixa mais lenta e regula sua evolução. (HALBWACHS, 2003, p.159)

O processo de exclusão ao qual grande parte dos negros, pobres e imigrantes foi submetida originou não só desdobramentos geográficos e sociais, mas também culturais. A fusão da tradição festiva europeia com as idiossincrasias da comunidade negra foi, gradativamente, tornando-se uma espécie de memória coletiva de um povo que transformou um lugar de descrença e cheio de preconceitos em um espaço de pertencimento - ainda que mal visto pelos que viviam além-morro. "Instrumentos trazidos da Europa como violões, violas, bandolins, flautas e sanfonas passavam a dialogar com atabaques, xequerês, ganzás e marimbas.” (NETO, 2017, p. 38)

Ainda segundo o jornalista Lira Neto (2017), as manifestações culturais relacionadas à música e à dança dos escravos foram rotuladas pelos brancos, de maneira genérica, como "batuques", e chamavam a atenção de imigrantes e viajantes estrangeiros no Brasil. Os principais ritmos e danças rurais identificados por todas as regiões brasileira, como o jongo do Sudeste, a embolada nordestina, o bambelô potiguar e o coco de praia cearense são oriundos dessas rodas de batuque. Essa riqueza cultural, posteriormente, teve contato com danças de salão e estilos musicais de origem europeia nos ambientes urbanos. Essa fusão originou 
Um gênero afro-brasileiro de música e dança que herdou a característica umbigada dos batuques angolanos, combinada com o estalar dos dedos, os braços elevados e as mãos à cintura típicos de bailados ibéricos, como o fandango espanhol. Era o lundu, o avô do samba. (NETO, 2017, p. 39).

Lins (2012) certamente não deixaria de ficcionalizar a mutação em que os gêneros musicais foram submetidos até resultarem no samba comumente conhecido. Brancura foi convidado por Valdirene, depois de um encontro com Seu Tranca-Rua, a ir ao aniversário da personagem Tia Almeida, uma mãe de santo que é apresentada com traços fortemente relacionados à Tia Ciata ${ }^{6}$. Em um primeiro momento, o sambista resistiu ao convite

Dizendo que estava enjoado daquela música que se ouvia lá. O schottisch, a valsa, a polca e o choro tocados na sala não caíam bem em seus ouvidos. O maxixe, executado na cozinha e nos quartos dos fundos da casa, chamado por eles de samba, era coisa para fazer criança dormir. Queria acordar o mundo com um ritmo pra frente. (LINS, 2012, p. 127)

Porém, Brancura viu-se cheio de felicidade ao chegar na casa de Tia Almeida e encontrar seus companheiros de malandragem e que hoje são considerados ícones do samba, como [Ismael] Silva, [Nilton] Bastos, [Mano] Edgar, Osvaldo Caetano Vasques, o Baiaco, e Alcebíades Maia Barcelos, conhecido por Bide e que havia desenvolvido, no romance, um instrumento musical chamado de tamborim. Ao longo da noite

[...] Foi-se de música em música por um bom tempo. Música de bater palmas, música de sapatear, música de miudinho, música de mãos nas cadeiras, melodia de umbigada, ritmo abraçadinhos. (LINS, 2012, p. 132-133)

Em determina passagem da noite, Tia Almeida pede para que os sambistas toquem "um samba desses modernos" (LINS, 2012, p. 133). O ritmo inovador que era nutrido pelos jovens músicos, mais rápido e sincopado, não agradou aos ouvintes que estavam presentes. Cada um dos compositores cantou uma música de autoria própria e fez com que as pessoas fossem se distanciando da roda criada. Desprezados, os amigos saíram da casa de Tia Almeida juntos e Silva principia a ideia um novo espaço de pertencimento,

\footnotetext{
${ }^{6}$ Hilária Batista de Almeida (1854-1924), Tia Ciata, desempenhava um papel de liderança comunitária na região da Saúde, Cidade Nova e Gamboa, no Rio de Janeiro. Era responsável por reunir um grande número de moradores das comunidades em sua casa, especialmente em dias festivos. Sua morada ficou conhecida como a capital da Pequena África - local habitado por escravos alforriados, prostitutas e pobres - e recebia grandes nomes do samba, como Pixinguinha, Donga, Heitor dos Prazeres, João da Baiana, Sinhô e Mauro de Almeida.
} 
onde os sambistas teriam a oportunidade de tocar o ritmo e as músicas que julgavam mais adequados:

- A gente tem que fazer a nossa sede, fundar um bloco de corda, entendeu? Ter um lugar pra gente cantar nosso samba pro povo. As músicas deles só foram gravadas porque todo o mundo já sabia de tanto eles cantarem nas festas. A casa de Tia Almeida é como se fosse um ponto de divulgação. Ali vai gente de gravadora, de jornal, de rádio. Então o pessoal vê o povo cantando e dançando, tem a certeza de que fica bom na voz desse ou daquele cantor. Se a gente fundar nosso bloco, fizer o nosso povo aprender nossas músicas, vai ser a mesma coisa insistiu Silva.

[...]- O que que tem que fazer pra fundar essa porra desse bloco logo? perguntou Brancura.

- Tem que ter uma porra de um presidente e um tesoureiro, em primeiro lugar. Fazer logo um livro de ouro ${ }^{7}$. [...] E quem quiser participar tem que pagar uma mensalidade para a gente alugar uma sede, comprar os instrumentos. É uma associação, não um clube, morou, meu capoeira? Isso pra gente não ficar levando bolachada dos besouros, porque senão eu vou acabar desistindo ou fazendo uma merda. (LINS, 2012, p. 134)

\section{O samba agoniza, mas não morre.}

Antes de propor uma reflexão sobre o desenvolvimento do bloco de cordas, é necessário que nos atentemos a uma das preocupações levantadas pelos malandros: "isso pra gente não ficar levando bolachada dos besouros". Rodrigues (2015) apresenta etimologicamente os sentidos que a palavra "favela" já possuiu: da botânica a um "espaço de exclusão" (PELLEGRINI, 2004). Com a abolição dos escravos, a chegada de imigrantes europeus pobres e a derrubada de cortiços do centro da cidade motivada pela política higienista do final do século XIX, inúmeras pessoas foram obrigadas a mudar para os diversos morros cariocas.

Evidentemente, houve a tentativa de um controle estatal sobre a população. De maneira quase sempre violenta, com inúmeros abusos de poder e com uma relação de respeito baseada no medo, Paulo Lins ficcionaliza o papel da polícia dentro da história do samba. Ao longo de todo o romance as personagens motivavam suas decisões a fim de evitar um confronto policial ou, quando se tornavam vítimas da instituição, julgavam suas ações:

\footnotetext{
${ }^{7}$ Livro em que se anotava nomes e valores doados para determinada instituição. As anotações ficavam à disposição para que a comunidade pudesse conhecer os doadores.
} 
[...] Mas o pior mesmo era quando juntava mais de cinco ou seis blocos para trocar bofetadas, rabo de arraia, meia-lua e tudo mais. A polícia também já gostava! Ô, raça desgraçada é essa raça de polícia. Não pode ver a negrada brincar em paz que já vem querendo bater. Às vezes, o bloco de sujos era só de família, de vizinhos que não se metiam em confusão, mas a polícia chegava batendo até em mulher, criança e velho. Não queria nem saber. Quando não tinha capoeira com navalha e arma de fogo, eles faziam o que queriam. (LINS, 2012, p. 45)

Além disso, o Código Penal da República dos Estados Unidos do Brasil de 1890 (promulgado pelo Decreto $n^{\circ} 847$ em 1890) em seus artigos 399 e 402 do capítulo XII, intitulado Dos vadios e Capoeiras, tratou de criminalizar a prática capoeirista e instituir a lei conhecida como Lei da Vadiagem:

Art. 399. Deixar de exercitar profissão, officio, ou qualquer mister em que ganhe a vida, não possuindo meios de subsistencia e domicilio certo em que habite; prover a subsistencia por meio de occupação prohibida por lei, ou manifestamente offensiva da moral e dos bons costumes.

[...] Art. 402. Fazer nas ruas e praças publicas exercicios de agilidade e destreza corporal conhecidos pela denominação capoeiragem; andar em correrias, com armas ou instrumentos capazes de produzir uma lesão corporal, provocando tumultos ou desordens, ameaçando pessoa certa ou incerta, ou incutindo temor de algum mal. ${ }^{8}$

No romance, Brancura agride Ivete quando ela vai ao bar onde o sambista estava para cobrar dele uma postura de chefe de família:

- Sabia que você estava enchendo a bacia com esses vagabundos. [...] - Vai pra casa, isso aqui não é lugar de mulher de família, não! - E é lugar de chefe de família? Tô em casa te esperando e você aqui nessa vagabundagem. Aposto que nem foi trabalhar. Eu tô cansada de você. Sem-vergonha, pilantra... (LINS, 2012, p. 76)

Depois da briga, Brancura vagou pelas ruas São Cláudio e Sampaio Ferraz. Acabava de ser promovido para fiscal de descarga de carvão no Cais do Porto. Começou a trabalhar porque tinha, junto com Ivete, um projeto para ascender a vida do casal. Desejavam abandonar os cômodos no alto do morro para morarem na Rua do Matoso, lugar (de) rico. A promoção amenizava o misto de sensações promovido pela briga, pelo álcool e pelo sono.

Já estava com a vida ruim, uma cerveja a mais não iria piorar. Assim que encheu o copo, uma viatura de polícia parou, um policial que já o havia prendido várias vezes o abordou.

\footnotetext{
${ }^{8}$ Disponível em http://legis.senado.gov.br/legislacao/ListaPublicacoes.action?id=66049. Acesso em 20 ago. 2017
} 
- Bom, hoje é sábado, não posso te aplicar uma vadiagem, mas como sei que você é vadio contumaz, incorrigível, assaltante, ladrão, macumbeiro e sambista, vou te fazer uma revista.

- Meu senhor, trabalhei a noite toda. Tô tomando essa cerveja aqui porque briguei com a patroa, senão estaria dormindo em casa.

- Só se foi na zona que tu trabalhou. Tu é vagabundo.

- O senhor quer ver meus documentos? Eu provo o que estou falando.

O policial examinou os documentos de Brancura, mesmo assim não acreditou. Disse que o documento era falsificado. (LINS, 2012, p. 76)

Mais uma vez, a polícia é representada como uma ferramenta de contenção social. Porém, em nenhum momento da narrativa é possível encontrar um comportamento abusivo ou violento com os moradores que não pertencem às margens urbanas. É evidente, então, que Lins se preocupa em ficcionalizar fatos reais que corroboraram para a perpetuação do preconceito e da segregação da comunidade negra, pobre e marginal não só do Rio de Janeiro.

A estratégia utilizada pelas personagens da narrativa para driblar o abuso policial foi unir os elementos culturais locais Samba e Umbanda. A subordinação da violência se deu em diversos momentos da narrativa. O primeiro deles - e talvez o mais simbólico foi quando foi quando o grupo de malandros decidiu que a sede do futuro bloco de cordas seria em um terreiro, após as sessões de Candomblé e Umbanda.

Os instrumentos de vanguarda para combater os de tortura como a chibata, a
gargalheira, o libambo, o tronco, os anjinhos, a máscara de flandres, o
bacalhau, o cacetete, o revólver, a pistola, a metralhadora, os ferros para marcar
a fogo... Até o vendo fazia a curva em causa própria, assim como as pessoas
que sentiam aquela energia vinda da criação artística para superar a vida em
que o povo negro da pós-escravidão colocou a cultura como arma para
conquistar dignidade com duas batidas fortes no surdo feito para entrar no
primeiro dos sambas de Bide com o ritmo lá em cima. Tiveram a ideia de fazer
parte da sociedade em forma de canto, mas mesmo assim foram espancados
pela polícia, sofreram desdém, foram presos, tiveram a dor do preconceito, mas
saíram sambando em busca de uma avenida para fazer dela uma passarela com
o reforço do tamborim, do reco-reco, da cuíca e do surdo. (LINS, 2012, p. 294)

Além disso, a própria ideia de criar um bloco que delimitava as pessoas que teriam acesso a ele serviu como uma espécie de barreira para a propagação da violência. Somente os mensalistas teriam acesso ao interior do bloco que seria composto pelo "pessoal da força” (LINS, 2012, p. 189) nos quatro cantos a fim de garantir segurança e ordem para evitar "pancada da polícia" (LINS, 2012, p. 189). A criação do bloco de cordas foi a demarcação de um espaço que só permitia a mobilidade de pessoas autorizadas e que nasceu com a finalidade de estabelecer fronteiras com a ilegalidade presente nas margens urbanas. Mais uma vez pode-se perceber o movimento descrito por Candido (1978) e que 
era realizado pelos tipos malandros: a facilidade com que transitavam entre a desordem social, cooperando com a corrupção de leis - tornando-se, por isso, vítimas do abuso policial -, e a organização civil, representada, no romance, pela necessidade da criação de barreiras (cordas) que acentuassem em qual dos lados o malandro se encontra.

Fica evidente, portanto, que as barreiras territoriais que o samba rompeu no romance não são apenas físicas, mas, também, simbólicas. O gênero musical é uma produção artística pertencente a um espaço de exclusão (PELLEGRINI, 2004) que buscou consagrar-se em um lugar de prestígio - centro da cidade. Para isso, entretanto, foi necessário que resistisse à violência policial, à segregação, aos olhares de uma sociedade que subjugava sua potencialidade artística.

Mesmo com a transformação do Samba em um elemento de brasilidade, com o rompimento de fronteiras simbólicas e físicas, com a sua aceitação por parte do centro da cidade, com sua apropriação por parte da indústria cultural, ainda hoje, quase um século depois do momento histórico ficcionalizado por Lins, o samba ainda sofre com medidas que visam diminuí-lo. Marcelo Crivella, atual prefeito do Rio de Janeiro, decidiu cortar pela metade a verba destinada para as escolas de samba em 2018, mesmo depois de garantir a permanência do patrocínio público durante sua campanha em 2016, como noticiou Mendonça (2017) no site G1 Rio.

O samba agoniza, mas não morre. Reinventa-se, orbitando entre os signos ancestrais da festa e da agonia. [...] Sinônimo de malandragem, viu-se perseguido pela polícia, entregou-se à vadiagem das ruas, perambulou pelos cabarés mais ordinários da zona do Mangue. No morro, foi morar nas ribanceiras das favelas, sem nunca abdicar dos apelos do asfalto. Vendido e comprado na surdina, tratado como produto clandestino, aos poucos foi sendo envolvido pelos códigos e engrenagens do grande mercado. Ladino, chegou ao disco, ganhou o rádio, virou astro de cinema. [...] Nasceu maldito e cativo. Cresceu liberto de amarras. (NETO, 2017, p. 25).

\section{REFERÊNCIAS BIBLIOGRÁFICAS}

ALMEIDA M. A. de. Memórias de um sargento de milícias. São Paulo: Ática, Série Bom Livro, 1991.

BOSI, A. Literatura e resistência. São Paulo: Companhia das Letras, 2002.

BRASIL. Decreto $\mathbf{n}^{\mathbf{0}}$ 847, de 11 de outubro de 1890. Promulga o Código Penal. Disponível em: http://legis.senado.gov.br/legislacao/ListaPublicacoes.action?id=66049. Acesso em: 20 ago. 2017.

CANDIDO, A. A dialética da malandragem. (Caracterização das "Memórias de um sargento de milícias"). Manuel Antonio de Almeida. Memórias de um sargento de milícias. Edição crítica de Cecília Lara. São Paulo: Livros Técnicos e Científicos Editora, 1978. 
Literatura e sociedade. São Paulo: Editora Nacional, 1985.

CERTEAU, M. de. A invenção do cotidiano: 1. Artes de fazer. Tradução de Ephraim Ferreira Alves. 5 ed. Petrópolis: Editora Vozes, 2000.

DALCASTAGNÈ, R. e AZEVEDO, L. (Orgs.) Espaços possíveis na literatura brasileira contemporânea. Porto Alegre: Zouk, 2015.

DAMATTA , R. Carnavais, malandros e heróis: para uma sociologia do dilema brasileiro. Rio de Janeiro: Guanabara Koogan, 1990.

DEALTRY, G. No fio da navalha: malandragem na literatura e no samba. Rio de Janeiro: Casa da Palavra, 2009.

DINIZ, J. O recado do morro - criação e recepção da música popular brasileira. In: OLINTO, H. K; SCHOLLHAMMER, K. E. (Orgs.). Literatura e cultura. Rio de Janeiro: Puc-Rio; São Paulo: Loyola, 2003. p.121-134.

DRUCKER, C. Resenha: Desde que o samba é samba. Revista Estação Literária (UEL). v. $10^{\mathrm{a}}$. Dezembro/2012. p. 242-246. Disponível em http://www.uel.br/pos/letras/EL/vagao/EL10A-Res2.pdf. Acesso em 16 ago. 2016.

EDMUNDO, L. O Rio de Janeiro do meu tempo. Rio de Janeiro: Conquista, 1957, p. 199.

ELIAS, N. e J. L. SCOTSON. Os estabelecidos e os outsiders. Tradução por: Vera Ribeiro. Rio de Janeiro: Zahar, 2000.

FONSECA, R. Romance negro e outras histórias. São Paulo: Companhia das Letras, 1992.

GALVÃO, W. N. Ao som do samba: uma leitura do Carnaval carioca. São Paulo: Fundação Perseu Abramo, 2009.

HALBWACHS, M. A memória coletiva. Tradução por: Beatriz Sidou. $2^{a}$ ed. São Paulo: Centauro, 2003.

HOLLANDA, H. B. de. Esses poetas: uma antologia dos anos 90. Rio de Janeiro: Aeroplano, 1998.

Entrevista com Paulo Lins. Homepage da autora. Disponível em: http://www.heloisabuarquedehollanda.com.br/?p=712 . Acesso em: 10 fev. 2015.

LINS, P. Cidade de Deus. São Paulo: Companhia das Letras, 1997.

Desde que o samba é samba. Rio de Janeiro: Planeta, 2012.

MATTE, G. A. Cidade de Deus: perversidade, fábula, utopia. In: PIETRANI, A.; BASTOS, D.; OLIVEIRA NETO, G.; FARIA, M. L. G. (Orgs.). V Encontro do Fórum de literatura brasileira contemporânea: ensaios e entrevistas. Rio de Janeiro: EdUerj, 2015. p.177-214.

MELO, M. B. M. de. Cidade de Deus: narrativa fílmica e romanesca. Dissertação (mestrado): Universidade Mackenzie. São Paulo, 2004.

MENDONÇA, A. V. Crivella diz que não vai voltar atrás sobre decisão de cortar verba para carnaval de 2018, G1 Rio, Rio de Janeiro, 19 jun. 2017.

NETO, L. Uma história do samba: volume I. São Paulo: Companhia das Letras, 2017. 
PAES, J. P. O pobre diabo no romance brasileiro. Novos Estudos CEBRAP. n. 20. Mar. 1988. pp. 38-53.

PELLEGRINI, T. As vozes da violência na cultura brasileira contemporânea. In:

Despropósitos.: estudos de ficção brasileira contemporânea. São Paulo: Annablume; FAPESP, 2008. p.177-206.

No fio da navalha: literatura e violência no Brasil de hoje. Estudos de Literatura Brasileira Contemporânea (UnB). n. 24, 2004. pp. 15-34.

PENNA, L. A. A bala e a fala. Cult. São Paulo. n. 6. jan. 1998. pp. 27-29.

PERLMAN, J. O mito da marginalidade: favelas e política no Rio de Janeiro. 3. ed. Trad. Waldivia Marchiori Portinho. São Paulo: Paz e Terra, 2002.

RIBEIRO, D. O povo brasileiro: a formação e o sentido do Brasil. $3^{a}$ ed. São Paulo: Global, 2015.

RODRIGUES, S. De Canudos para o Brasil: a história da palavra favela. Sobre palavras. 2012. Disponível em: Acesso em: 10 fev. 2015.

ROCHA, João Cezar de Castro. A guerra de relatos no Brasil contemporâneo. Ou: A dialética da marginalidade. Revista Letras (UFSM). v. 28-29. Janeiro-dezembro 2004. p. 153-184. Disponível em: http://periodicos.ufsm.br/letras/article/view/11909. Acesso em: 10 fev. 2015.

SCHOLLHAMMER, K. E. A violência como desafio para a literatura brasileira contemporânea. In: __ Cena do crime: violência e realismo no Brasil contemporâneo. Rio de Janeiro: Civilização Brasileira, 2013. p.39-103.

Ficção brasileira contemporânea. Rio de Janeiro: Civilização Brasileira, 2011.

SILVA, M. C. Crítica Sociológica. In: BONNICI, T. e ZOLIN, L. O. (Org.) Teoria Literária: abordagens históricas e tendências contemporâneas. EUEM, Maringá, 2009. P. 177-188.

The 21st Century's 100 greatest films. Disponível em: http://www.bbc.com/culture/story/20160819-the-21st-centurys-100-greatest-films Acesso em: 29 ago. 2016.

VIANNA, H. O mistério do samba. Rio de Janeiro: Zahar, 2012. $2^{\mathrm{a}}$ ed. 


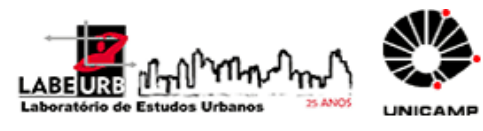

\section{Para citar essa obra:}

FERRONE, Gabriel Capelossi. O filho da dor: espacialidades em Desde que o samba é samba, de Paulo Lins. In: RUA [online]. nº 23. Volume 2, p. 187 - 202 -e-ISSN 2179-9911 - Novembro/2017. Consultada no Portal Labeurb - Revista do Laboratório de Estudos Urbanos do Núcleo de Desenvolvimento da Criatividade.

http://www.labeurb.unicamp.br/rua/

Capa: Detalhe da capa do livro Desde que o samba é samba, de Paulo Lins. Disponível em < https://pladlivrosbr1.cdnstatics.com/usuaris/libros/fotos/168/original/desde-que-o-samba-esamba_9788576658078.jpg >

\section{Laboratório de Estudos Urbanos - LABEURB}

Núcleo de Desenvolvimento da Criatividade - NUDECRI

Universidade Estadual de Campinas - UNICAMP

http://www.labeurb.unicamp.br/

Endereço:

LABEURB - LABORATÓRIO DE ESTUDOS URBANOS

UNICAMP/COCEN / NUDECRI

CAIXA POSTAL 6166

Campinas/SP - Brasil

CEP 13083-892

Fone/ Fax: (19) 3521-7900

Contato: http://www.labeurb.unicamp.br/contato 